レター

\title{
任意の対象人物への非装着型音声伝達システムのための基礎検討
}

\author{
大 谷 拓 也*1 棌潚 ${ }^{* 2}$ 小 川 駿 也*3 鈴 木 滋 英*3 \\ 山田晃 久 $* 3$ 小西瑶 果 $* 3$ 清 水 智 壮*3 \\ 正 宗 賢 $* 2$ 村 垣 善 浩 $* 2$ 高 西 淳 夫*3*4
}

\section{Basic Study for Non-wearable Voice Transmission System to Target Person}

\author{
Takuya Otani*1, Xiao Sun*2, Shunya Ogawa*3, Jiei Suzuki*3, \\ Akihisa Yamada*3, Yoka Konishi*3 ${ }^{* 3}$ Tomoaki Shimizu*3, \\ Ken Masamune ${ }^{* 2}$, Yoshihiro Muragaki*2 and Atsuo Takanishi*3*4
}

\begin{abstract}
In a small room such as an operating room where there are multiple staff, some orders should be transmitted to a selected person. For achieving this without any wearable devices, we developed a voice transmission system using a parametric speaker. To use a parametric speaker in a small room, we had some experiments to investigate sound pressure characteristics in a small room and understandability of the transmitted voice with MOS. As a result, it was confirmed that the transmitted voice, which has possibility that reflect on the wall and reach to a not selected person, could be heard clearly.
\end{abstract}

Key Words: Voice Transmission, Parametric Speaker, Robotics, Operating Room

\section{1.は じめに}

外科手術には多くのス夕ッフが携わりそれぞれ多種多様な夕 スクを担っている，手術室内は，患者への細菌やウイルスの付 着が万が一にも起こらないよう衛生管理を徹底するため，患者 自身だけでなく患者に接触する物品への接触の可能性のある手 術室内のスタッフは手術室への入退室の度に清潔を維持するた めのマスク・帽子・手袋・術衣着用などの衛生対策を行い，特 に術者は滅菌対応に十分に気を配ることが求められる。 そのよ うな環境下において，各スタッフ間もしくは外部から術者等へ 情報伝達を行う必要があるが，全員が共有する必要がなく特定 の人物にのみ伝えたい情報も多い. 特に音声での作業指示や指 導は頻繁に行われるが，これをスタッフ全体に共有すると余計 な情報を処理するために本来のタスクへの集中を乱してしまう. 特定の人物への情報伝達手段としてイヤホンの使用が考えられ 製品化もされているが, 冒頭で述べた衛生管理を徹底するため, 手術室内スタッフは可能な限り身に付ける物品を減らすことが 望ましい. そこで, 強い指向性を持つ音声を出力可能なパラメ トリックスピーカに着目した，パラメトリックスピーカは，約

原稿受付 2020 年 8 月 3 日

*1早稲田大学理工学術院総合研究所

*2東京女子医科大学

*3早稲田大学理工学術院

*4早稲田大学ヒューマノイド研究所

${ }^{* 1}$ Waseda Research Institute for Science and Engineering, Waseda University

${ }^{* 2}$ Tokyo Women's Medical University

${ }^{* 3}$ Faculty of Science and Engineering, Waseda University

${ }^{* 4}$ Humanoid Robotics Institute, Waseda University

ロ 本論文は新規性（要素分野）で評価されました。 $60[\mathrm{deg}]$ 程度の指向性を持つ超音波を発生する超音波スピーカ素 子を同平面上に複数個並べることで, 指向性を高めたスピーカで ある [1]. 狭い空間にピンポイントに音声を伝達可能なため, ア ミューズメント施設でのアトラクション説明などに利用されて いる [2]. また，非常に高い指向性を持つため壁面での反射を利 用して壁面を介した音声伝達などの用途も注目されている [3] [5]. 木村らは映像を映しているスクリーンの特定の位置に音波 を当てて反射させたうえで視聴者に音声を伝えることによる音 像提示を提案している [3]. 西浦は複数のパラメトリックスピー カを集約したユニットから音声を放射することで壁や天井に反 射させた三次元音像提示を実現している [4]. 長尾らはガラス面 に音を反射させることで特定位置の鑑賞者に特定方向からの音 声提示を提案している [5].

本研究が対象とする作業中の人物への音声伝達では, 音声伝 達対象の人物を適宜選択しその人物にのみ正確に音声を出力で きる必要があるが, 先行研究では広い空間における音声提示を 行っているのに対し, 手術室のような狭い室内に複数人のスタッ フが存在する場面では, パラメトリックスピーカの特性である反 射音も可聴であることおよび音の減衰が少ないことにより, 対 象者以外の人物も音声を聞き取る可能性がある。 そのため, 狭 い空間内での壁面反射も含めたスピーカ音圧特性を調査する必 要がある.また，出力される音声がコミュニケーションに十分 な品質である必要がある.

本研究では, 手術室内の特定のスタッフのみへの音声伝達を 可能とする非装着型音声伝達システムを開発し, その性能を調 査した。具体的には，操作者が手術室内の映像を確認しながら 任意の対象人物へパラメトリックスピーカの向きを操作し発話 することが可能なシステムを製作した。 また，手術室内でのコ 
ミュニケーションに向けて，特に先行研究で想定される環境に 対し狭い屋内環境での複数回の音響反射を含めた音圧特性およ びコミュニケーションのため音声の理解度などを調査したため 報告する。

\section{2. 非装着型音声伝達システム}

\section{1 要求仕様}

特定の人物のみへの音声伝達を実現するため, 以下の要求仕 様を定めた。音圧の目安として，騒音などの目安より，通常会 話および静寂な室内の音圧を要求仕様とした $[6]$.

・音声伝達対象者への物理的接触は行わない

・音声伝達対象者が意味を十分にストレスなく理解可能な音 質の伝達が可能である

・音声伝達対象者への音圧は十分に聞こえるよう $60[\mathrm{~dB}]$ 程度

・対象者以外への音圧は静寂程度の $40[\mathrm{~dB}]$ 以下

\section{2 システム詳細}

本システムは, パラメトリックスピーカ, マイク, Pitch, Yaw 方向の角度調整用の 2 軸能動駆動部, 手術室内の映像を確認す るための USB カメラ, 各機器をコントロールする Raspberry Pi から成る. システム構成図を Fig. 1 に，実機外観を Fig. 2 に示す。広い視野を取れるよう部屋内の天井に設置することを 想定して軽量とし, 本研究のパラメトリックスピーカには, 入手 性が高く安価な超音波スピーカ素子 (UT1007-Z325R) を 50 個 用いた。周波数変調を行った超音波を通常周波数の超音波の 2 種類を同時に発生させることで，2 種の超音波の周波数差のうな りとして可聴域の音が生成される。パラメトリックスピーカを 対象人物に向けるため, パラメトリックスピーカの真下にUSB カメラを搭載し, USB カメラの画角の中心とスピーカの正面 が一致するようにした. Console PC-1 および Console PC-2, Raspberry Pi はそれぞれ ROS を介して通信を行う。操作者は Console PC-1 画面上に表示されたカメラ映像を見ながら，音 声伝達対象人物がカメラ映像の中央にくるようにキー操作する ことで，その人物にスピーカを向けることができる。この際， Console PC-1 から Raspberry Pi にモー夕位置指令が送られ, さらにマイコン (Nucleo-F401RE, STMicroelectronics Inc.) を介してモータへ制御指令が送られる. Console PC-1には発 話者用マイクとスピーカが, Console PC-2 にはパラメトリッ クスピーカと音声伝達対象者用マイクが接続されており, マイ クから取得した音声を相互のスピーカで再生することで会話も 可能である.

パラメトリックスピーカの方向調整用の Yaw-Pitch 2 軸能動 駆動部には，角度のフィードバック不要で位置制御が可能であ り, 同じ姿勢の維持に比較的適したステッピングモータを用い たＹYaw 軸駆動用モータはプーリとベルトを介して回転軸に動 力を伝達し，これにより重心位置の調整が容易となっている. また, Pitch 軸駆動用モー夕は Pitch 回転軸を直接駆動する方 式とし，スピーカおよびカメラの重量分を相殺するようカウン タウェイトをスピーカ裹に配置し回転軸上に重心位置がくるよ うに設計することで，モータの必要トルクを低減し，モータの 小型化・消費電流の低減を行った $($ Fig. 3). Yaw 方向回転軸 のシャフトには鉛直下向きに重力が加わるため，ボディ下側の ベアリングにはラジアル荷重とアキシアル荷重の両方を支える ことができるニードルベアリングを使用した．対象人物に狙い を絞った方向調節が可能なよう，2 軸能動駆動部によりスピー カおよびマイクの角度は Yaw 方向に $1.2[\mathrm{deg}]$ および Pitch 方

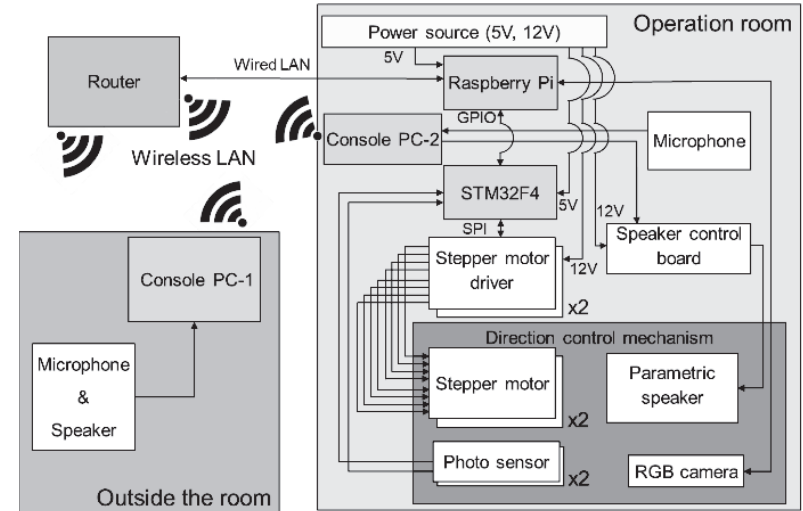

Fig. 1 Schematic view of the developed system

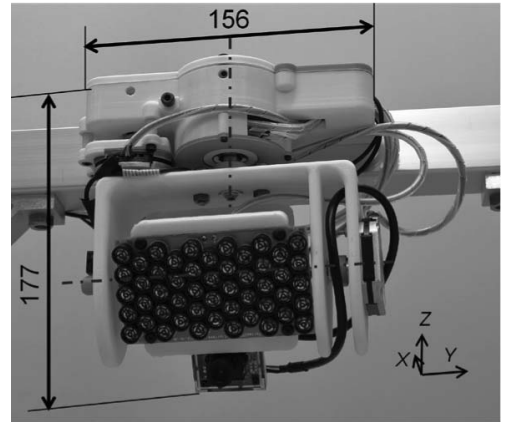

Fig. 2 Developed voice transmission system

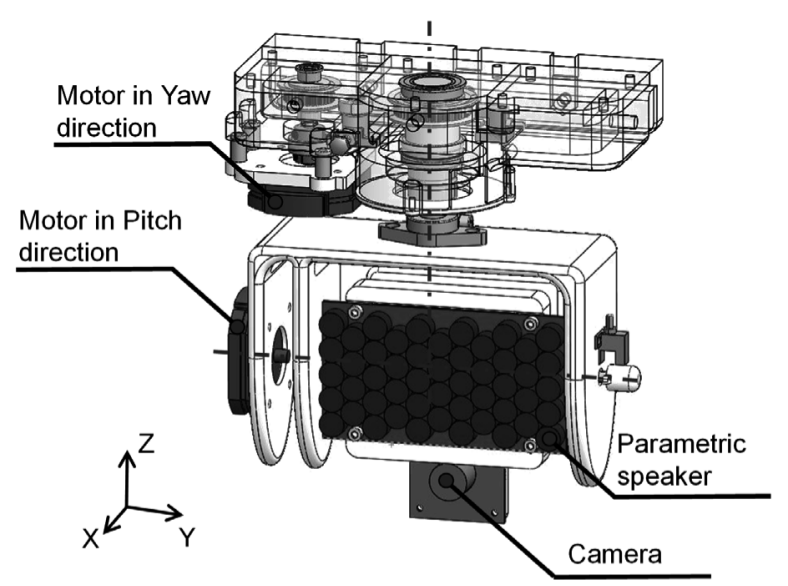

Fig. 3 CAD of the developed system

向に $1.8[\mathrm{deg}]$ ずつ回転させられる.これにより, 音声伝達対象 者がスピーカから $3[\mathrm{~m}]$ の位置にいたとしても，Yaw 方向に約 $6.2[\mathrm{~cm}]$ ごとに音声伝達対象位置の調整が可能である. 回転軸 にはフォトセンサを搭載しスピーカの初期角度補正を可能とし た. 構成部品以外の構造部材は全体の軽量化のため有限要素法 解析を行い強度を確認した上で（Fig. 4), PLA（Poly-Lactic Acid）樹脂の $3 \mathrm{D}$ プリンタ出力により成形した。製作した音声 伝達システムの緒元を Table 1 に示す.

\section{3. 評価実験と考察}

\section{1 室内でのスピーカ音圧特性計測}

本実験では，開発したシステムにおいて特定人物のみへの音 声伝達が可能であることを確認するため，スピーカから各位置 における音圧を測定した。実験方法は, 音圧測定器をスピーカ 正面の $1,2,3[\mathrm{~m}]$ の距離の位置に配置し，スピーカから一定音 


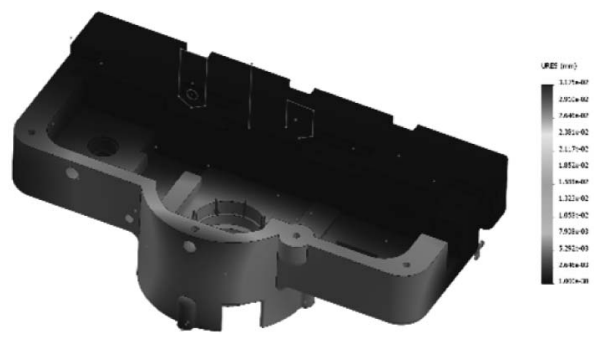

Fig. 4 Finite element method analysis of a base part of the developed system. From the analysis, the maximum deflection is less than $0.004[\mathrm{~mm}]$

Table 1 Specifications of the system

\begin{tabular}{|c|c|}
\hline Features & Values \\
\hline Size mm & $70 \times 156 \times 177$ \\
\hline Weight kg & 0.83 \\
\hline Movable angle in Pitch deg & \pm 90 \\
\hline Movable angle in Yaw deg & \pm 90 \\
\hline Resolution in Pitch deg & 1.8 \\
\hline Resolution in Yaw deg & 1.2 \\
\hline Rotational speed in Pitch deg/s & 270 \\
\hline Rotational speed in Yaw deg/s & 180 \\
\hline
\end{tabular}

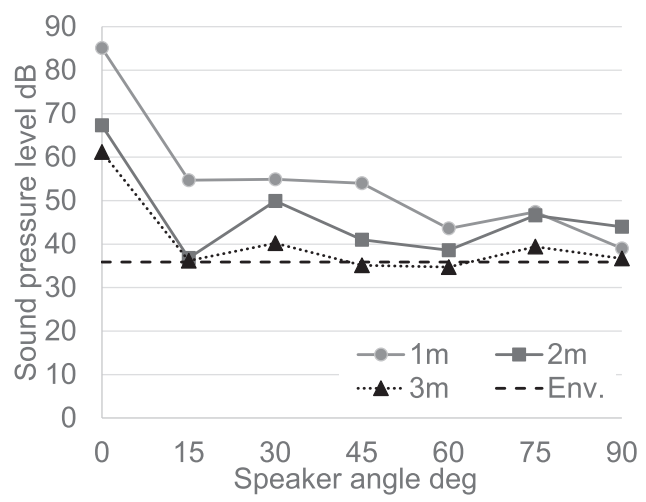

Fig. 5 Sound pressure level at three measuring points when the speaker angle was changed

量, 一定周波数 $(400[\mathrm{~Hz}])$ の音声を再生しながら, 正面に対し スピーカを $0,15,30,45,60,75,90[\mathrm{deg}]$ 回転させた場合の音 圧を測定した。また，スピーカからの音声を出力していない状 態で実験環境の音圧も測定した。

結果を Fig. 5 に示す. 実験結果より, 要求仕様としたとお り，スピーカ正面とそれ以外で大きな音圧差が実現されている ため対象人物にのみ聞き取りやすい音声伝達が実現できること が分かった．また，測定位置がスピーカに近いほうが音圧は大 きく測定位置が遠くなるにつれて音圧は小さくなるが，これは 音の減衰の影響であると考えられる，しかし，スピーカの角度 が音圧測定器からずれていくほど音圧が小さくなるわけではな く，測定位置が $1[\mathrm{~m}]$ の場合は $15[\mathrm{deg}]$ から $45[\mathrm{deg}]$ までは大 きな変化がなく, $2,3[\mathrm{~m}]$ の場合は $30,75[\mathrm{deg}]$ ずれたときに 音圧が上昇している。これは実際に聞いても違いを感じられる ため, 音声伝達の対象者以外の人物が音圧測定器の位置にいた

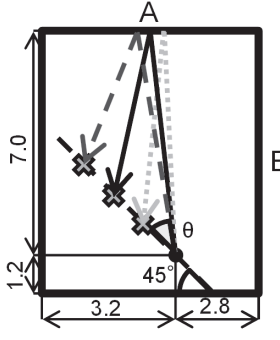

(a) Wall A

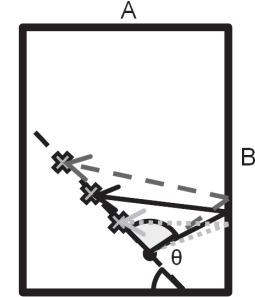

(b) Wall B

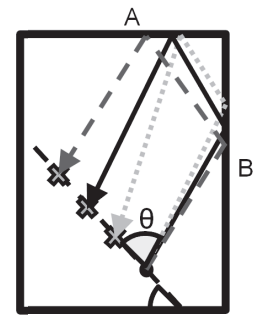

(c) Wall A and B
Fig. 6 Sound reflection in the experiment. Three cross marks mean the point of sound pressure measuring instruments. A dotted line means a path to a sound pressure measuring instruments at a distance of $1[\mathrm{~m}]$ from the speaker, a solid line: $2[\mathrm{~m}]$, a broken line: $3[\mathrm{~m}]$

Table 2 Angles at which the voice reaches due to sound reflection on the wall

\begin{tabular}{|c|c|c|}
\hline \multirow{4}{*}{ Wall } & Measure point $\mathbf{~}$ & Angle $\boldsymbol{\theta}$ deg \\
\hline \multirow{4}{*}{ A } & 1.0 & 42 \\
\cline { 2 - 3 } & 2.0 & 39 \\
\hline \multirow{4}{*}{ B } & 3.0 & 35 \\
\cline { 2 - 3 } & 1.0 & 129 \\
\cline { 2 - 3 } & 2.0 & 123 \\
\hline \multirow{3}{*}{ A and B } & 3.0 & 119 \\
\cline { 2 - 3 } & 1.0 & 70 \\
\cline { 2 - 3 } & 2.0 & 74 \\
\hline
\end{tabular}

場合に音声が伝わってしまうことを示している。しかし，音波 がスピーカから直接音圧測定器に届いたのではなく, 壁面で反 射して届いたものと考えられる. 本実験で使用した条件の場合， スピーカの角度をずらしていった際にも，壁面 $\mathrm{A} ， \mathrm{~B}$ およびそ の両方での反射が起きうる（Fig. 6). 各反射が起きてスピーカ に音声が届いた場合のスピーカ角度を Table 2 にまとめる。こ の結果より, 室内の大きさおよびスピーカ位置, 音声伝達対象者 の位置によっては，壁面反射により対象の人物以外にも音圧は 大きくないものの音声が届く可能性が示唆された.これは, 壁 面に吸音材を設置するなど反射抑制対策を施すことや，提案シ ステムを複数台設置し対象人物を正確に狙うことができる場所 から音声放射することによっても解決可能であると考える。ま た，本実験では出力音圧を一定で実験を行っているため，比較 的距離の近い位置には大きい音圧のまま音声が届いていること も考えられる. 対象者への距離に合わせて出力すべき音圧は推 定可能であるため, 対象者までの距離を計測あるいは推定し音 圧を制御することにより，対象外の人物にも意味を理解可能な 音声が届くことを防ぐことができる，さらに，本研究で対象に した小さい部屋の場合は壁で反射した音声がまた別の壁で反射 して, 音圧測定器に届くことが確認できた. 先行研究でもパラ メトリックスピーカの出力音声を壁に反射させることで特定方 向からの音源位置定位を可能にしているものがあるが，本研究 のような小さい空間の場合，複数の壁の反射を利用することで さらに多方向からの音声伝達が可能であり, 障害物やスタッフ 
Table 3 MOS value in the experiment

\begin{tabular}{|c|c|c|}
\hline Speaker & Sound quality & Understandability \\
\hline Male & 3.67 & 4.60 \\
\hline Female & 4.17 & 4.68 \\
\hline Average & 3.92 & 4.64 \\
\hline
\end{tabular}

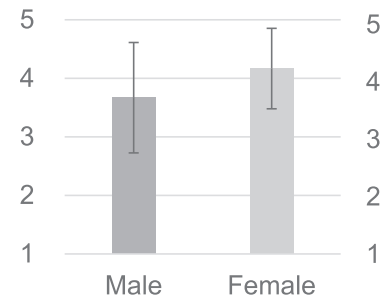

(a) Sound quality

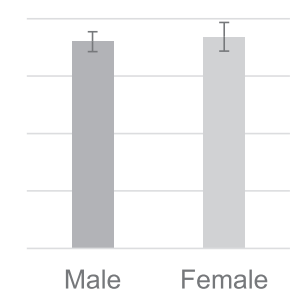

(b) Understandability
Fig. 7 Experimental results of subjective evaluation

を考慮して出力方向を変えることが有効であると考えられる．

\section{2 音質の主観評価}

提案するシステムを用いた音声伝達がコミュニケーションに 使用できるかを確認する主観評価実験を行った．室外の話者が マイクに向かって短文を読み上げた音声を室内のスピーカから 流し，その音質と内容の理解度を調査した。聞き取る評価者は 6 名とし， 2 名の話者にそれぞれ別々の 10 種類の平易な短文を 順番に読み上げてもらった，短文の例を以下に示す。

・彼の足の怪我は，1 个月経っても一向に良くならなかった.

・部屋の掃除をするついでに, ベッドの位置も変えた.

被験者は，それぞれの文について内容が理解できたか，および 実験全体を通して音質が良いと感じたかどうか，について悪い 場合を“1”，良い場合を“5”とする 5 段階で評価してもらいそ れらの平均をとる, 音声通話の品質評価によく用いられる MOS (Mean Opinion Score) 評価の手法を用いた.

実験結果を Table 3 および Fig. 7 に示す．算出した MOS 值によると，男性話者が話した場合の音質は少し低いものの，音 質は平均して 3.92, 理解度は 4.64 となり, また理解度の標準偏 差も約 0.2 程度であり，音声理解に十分使用可能であることが 確認できた.

\section{4. 結論と今後の展望}

本研究では, 手術室に扔ける医療従事者への非装着型音声伝 達システムを開発した，指向性の高いパラメトリックスピーカ の方向を操作者が操作可能なシステムとすることで，任意の対 象人物への音声伝達を可能とした。評価実験として，室内にお けるスピーカからの距離および角度の違いによる音圧を測定し, 正面の人物とそれ以外の人物が受け取る音圧に大きな違いが実 現できていること，および壁面反射音により特定の位置での音 圧上昇が生じていることを確認し，また音質や音声の理解度に ついてもコミュニケーションに十分であることを MOS 評価に より確認した。

今後は，実環境での運用試験を進めていく．また，音圧評価 実験にて明らかになった壁面反射についても，反射音を低減す る対策とともに，反射特性を利用することでスピーカと対象者 間に障害物がある場合の複数の壁面反射を活用した音声伝達に ついても検討を進める。これにより，音声伝達対象者への音声 伝達経路が複数存在する場合に，障害物やスタッフが存在しな い経路を選択する手法の確立を目指す。

謝 辞 本研究は早稲田大学理工学術院総合研究所および早 稲田大学ヒューマノイド研究所, 早稲田大学次世代ロボット研 究機構の下で実施された。 また，本研究で用いられた 3DCAD はソリッドワークス・ジャパン株式会社より提供された。各社・ 官公庁に感謝する。

\section{参 考 文 献}

[1] P.J. Westervelt: "Parametric acoustic array," The Journal of Acoustical Society of America, 35, pp.535-537, 1963.

[ 2 ] M. Yoneyama, J. Fujimoto, Y. Kawamo and S. Sanabe: "The audio spotlight: An application of nonlinear interaction of sound waves to a new type of loudspeaker design," The Journal of Acoustical Society of America, vol.73, pp.1532-1536, 1983.

[ 3 ] 木村, 宝珠山, 谷川, 廣瀬： “超指向性スピーカーによる大画面上音 像提示システム”, 電子情報通信学会技術研究報告. MVE, マルチメ ディア・仮想環境基礎, vol.110, no.108, pp.1-6, 2010.

[4] 西浦：“パラメトリックスピーカを用いた音場再生技術”，日本音響学 会誌, vol.71, no.2, pp.89-94, 2015.

[5] 長尾，苗村：“超指向性スピーカー群を用いた鑑賞支援システムの基 礎検討”, 電子情報通信学会技術研究報告. MVE, マルチメディア· 仮想環境基礎，vol.112, no.25, pp.29-34, 2012.

[6] 建築設計資料集成〈1〉環境. 日本建築学会, 2001 . 